\title{
Replacement of Fishmeal By 60\% with Soybean Meal or Peanut Meal in Diets for Juvenile Mangrove Red Snapper (Lutjanus argentimaculatus) (Forsskål, 1775)
}

\author{
Xiaoyi Wu*, Qi Yu, Shuntian Jiang and Yuan Luo \\ Department of Aquaculture, Hainan University, China
}

Submission: February 17, 2016; Published: March 25, 2016

"Corresponding author: Xiaoyi Wu, Department of Aquaculture, Ocean College, Hainan University, Haikou 570228, China, Tel: +86-089866279184; 979-676-0618; Email: wjurk@163.com

\begin{abstract}
A feeding trial was undertaken to develop a low fishmeal practical diet for mangrove red snapper (Lutjanus argentimaculatus) by replacing $60 \%$ fishmeal (FM) protein with either soybean meal (SM) or peanut meal (PM) and $10 \%$ fish solubles (FS) or krill solubles (KS) supplementation. Seven isonitrogenous (crude protein: 40\% dry matter) and isolipidic (crude lipid: 9\% dry matter) diets were prepared [Diet 1 / FM100, Diet 2 / (FM40+SM), Diet 3 / (FM40+SM+FS), Diet 4 / (FM40+SM+ KS), Diet 5 / (FM40+PM), Diet 6 / (FM40+PM+FS), Diet 7 / (FM40+PM+ KS)]. Triplicate groups of fish (initial body weigh: $1.46 \pm 0.02 \mathrm{~g}$, mean \pm S.D.) were stocked in 150-l circular fiberglass tanks at a density of 18 fish per tank. Fish were hand fed the respective experiment diets to satiation twice a day for 56 days. Results showed that there were no significant ( $p>0.05$ ) differences in values of final body weight (FBW) or weight gain (WG) among the fish fed with the FM100 diet and those fed with (FM40+SM), $(\mathrm{FM} 40+\mathrm{SM}+\mathrm{FS})$ and $(\mathrm{FM} 40+\mathrm{SM}+\mathrm{KS})$ diets. For fish fed with the (FM40+PM) diet, WG were significantly lower when compared to fish fed with the other experiment diets. Supplementation of $10 \%$ FS or KS improved growth parameters of fish fed with PM-containing diets. Feed efficiency (FE), protein efficiency ratio (PER) and protein productive value (PPV) showed similar tendencies as growth indices. No significant differences in feed intake (FI) values were observed among different dietary treatments. Morphological indices, as well as whole-body compositions showed marked variations among different groups. Plasma parameters were not significantly affected by dietary treatments. The present study indicates that $60 \%$ of fishmeal protein could be replaced by soybean meal or by a mixture of peanut meal and $10 \%$ FS or KS without affecting the growth performance of Lutjanus argentimaculatus.
\end{abstract}

Keywords: Lutjanus argentimaculatus; Fishmeal; Soybean meal; Peanut meal; Growth

Abbreviations: FM: Fish Meal; SM: Soybean Meal; PM: Peanut Meal; FS: Fish Solubles; KS: Krill Solubles; FBW: Final Body Weight; WG: Weight Gain; FE: Feed Efficiency; PER: Protein Efficiency Ratio; PPV: Protein Productive Value; FI: Feed Intake; TP: Total Protein; CHOL: Cholesterol; TG: Total Tricylglycerol; HDL-C: High Density Lipoprotein Cholesterol; CF: Condition Factor; HSI: Hepato Somatic Factor; IPF: Intra Peritoneal Fat; LDL-C: Low Density Lipoprotein Cholesterol; ANOVA: Analysis of Variance

\section{Introduction}

Recently, FAO [1] reported that about $80 \%$ of the world fish stocks of pelagic marine fish are either fully or over-exploited, meaning fishmeal supply is facing shortage of resources. Therefore, many nutritionists are investigating the possibilities of fishmeal replacement by plant protein sources in fish diets along with optimizing diet formulations [2,3]. Based on previous results, it has been observed that various fish species respond differently to dietary plant protein replacement of fishmeal or other seafood by-product feedstuffs [4-6].

Soybean meal and peanut meal are widely used as alternatives to fishmeal in aquatic animal diets in China. It has been demonstrated that soybean meal can be successfully used to partially or totally replace fishmeal in many fish species [5-9]. Peanut meal has an annual production of 300 millions in China [10]. Our previous study indicated that peanut meal had a high potential of replacing dietary fishmeal in Yellowfin Seabream diets based on its high apparent protein digestibility by this fish [11]. It could be observed from some published papers [1214] that different fish species probably had different responses to high dietary peanut meal levels. Given that high inclusion levels of plant proteins in carnivorous or marine fish diets have potential negative effects such as amino acid imbalance, reduced palatability or absence of some free amino acids, feeding stimulants are often supplemented when replacing fishmeal. 
Fish solubles and krill meal are reported to have a positive effect on stimulating growth of Atlantic salmon [15] and red sea bream $[5,16]$ given diets high in plant protein feedstuffs.

The mangrove red snapper (Lutjanus argentimaculature), an euryhaline, hardy and fast growing fish capable of tolerating stress and crowding [17], has been considered as an emerging aquaculture species in the tropical and sub-tropical countries about 20 years ago [18]. Aquaculture of this fish species has become immensely popular in Southeast Asia and Australia due to its high market price [19]. In recent years, mangrove red snapper is also being more concerned in south of China.

There is less available information on Lutjanus argentimaculature nutrition. Previous research works showed that a $43 \%$ dietary protein level would be suitable for the fast growth of Lutjanus argentimaculature [20,21]. Catacutan and Pagador [22] reported that $25 \%$ fishmeal protein could be replaced by soybean meal without negative effects on growth of this fish species at a $50 \%$ dietary protein level. A published study of Kader et al. [16] showed that $60 \%$ FM protein could be replaced by plant protein feedstuffs in red sea bream diets when supplemented with FS and krill meal. Based on the information above, the objective of this experiment was to develop a fish meal low diet for juvenile mangrove red snapper by replacing $60 \%$ fishmeal (FM) protein by soybean meal (SM) or peanut meal (PM) with a $10 \%$ FS or KM supplementation.

\section{Materials and Methods}

\section{Experimental diets and diet preparation}

Seven isonitrogenous (crude protein: $40 \%$ of dry matter) and isolipidic (crude lipid: 9\% of dry matter) diets comprising a high fishmeal control diet and six different low-FM diets were prepared (Table 1) [23]. Dietary protein level in this study was close to the optimal level of $43 \%$, reported by Abbas and Siddiqui [21]. In this experiment, a $60 \%$ replacement level of FM protein by dehulled, solvent-extracted SBM or PM was designed, being referenced from a previous study of Kader et al. [16], which showed that $60 \%$ FM protein could be replaced by plant protein feedstuffs in red sea bream diets when supplemented with FS and krill meal. It was reported that FS or KS contain comparatively balanced amino acids and high amount of free amino acids $[15,24,25]$, so in this study, a crystalline amino acid mixture was only supplemented in low-FM diets without FS and KS. All dry ingredients were well ground, weighed and mixed in a Hobart mixer (A-200T Mixer Bench Model unit, Resell Food Equipment Ltd., Ottawa, Canada) for $30 \mathrm{~min}$; after which, oil was gradually added, while mixing constantly. Then, 30-50 mL of water was slowly blended into the mixture for each $100 \mathrm{~g}$ of dry matter, resulting in suitably textured dough. The diets were produced in a noodle-like shape of $1.5 \mathrm{~mm}$ in diameter using a twin-screw extruder (Institute of Chemical Engineering, South China University of Technology, Guangzhou, PR China). Then the diets were sun-dried for $4 \mathrm{~h}$, sieved and stored at $-20^{\circ} \mathrm{C}$ until fed.

Table 1: The composition of the experimental diets (\% dry-matter basis).

\begin{tabular}{|c|c|c|c|c|c|c|c|}
\hline \multirow{2}{*}{ Ingredient } & \multicolumn{7}{|c|}{ Diet Designation } \\
\hline & (FM100) & $(\mathrm{FM} 40+\mathrm{SM})$ & $(\mathrm{FM} 40+\mathrm{SM}+\mathrm{FS})$ & $(\mathrm{FM} 40+\mathrm{SM}+\mathrm{KM})$ & $(\mathrm{FM} 40+\mathrm{PM})$ & $(\mathrm{FM} 40+\mathrm{PM}+\mathrm{FS})$ & $(\mathrm{FM} 40+\mathrm{PM}+\mathrm{KM})$ \\
\hline $\begin{array}{c}\text { Peruvian } \\
\text { fishmeal(Anchovy) }^{1}\end{array}$ & 50 & 20 & 20 & 20 & 20 & 20 & 20 \\
\hline Soybean meal $^{2}$ & & 45 & 37 & 37 & 0 & 0 & 0 \\
\hline Peanut meal $^{3}$ & 0 & 0 & 0 & 0 & 42 & 34 & 34 \\
\hline Fish solubles ${ }^{4}$ & 0 & 0 & 10 & 0 & 0 & 10 & 0 \\
\hline Krill solubles $^{5}$ & 0 & 0 & 0 & 10 & 0 & 0 & 10 \\
\hline CAA mixturea & & 2 & 0 & 0 & 2 & 0 & 0 \\
\hline Fish oil & 2.0 & 4.5 & 4.0 & 4.0 & 4.5 & 4.0 & 4.0 \\
\hline Soybean lecithin & 1 & 1 & 1 & 1 & 1 & 1 & 1 \\
\hline Cellulose & 20.2 & 0.7 & 1.2 & 1.2 & 3.7 & 4.2 & 4.2 \\
\hline Othersb & 26.8 & 26.8 & 26.8 & 26.8 & 26.8 & 26.8 & 26.8 \\
\hline \multicolumn{8}{|c|}{ Proximate composition(\%) } \\
\hline Dry matter & 95.0 & 95.3 & 94.5 & 92.8 & 93.4 & 95.4 & 93.1 \\
\hline Crude protein & 39.2 & 39.9 & 40.9 & 40.8 & 41.5 & 40.8 & 40.1 \\
\hline Crude lipid & 9.1 & 8.8 & 8.5 & 9.1 & 8.7 & 9.9 & 9.3 \\
\hline Crude ash & 11.8 & 10.1 & 11.0 & 12.1 & 10.3 & 10.1 & 11.3 \\
\hline
\end{tabular}

aCrystalline amino acid mixture: $0.5 \%$ for each of lysine, methionine, taurine, glycine.

${ }^{b}$ Others: Wheat flour 22\%, Vc $0.3 \%$, Vitamin mixture $1 \%$, Mineral mixture $3 \%$, Choline chloride (50\%) $0.5 \%$ 
Vitamin mixture contained (as kg-1 dry diet): retinol_IU. 50 000; cholecalciferol _IU. 2000; a-tocopherol _IU. 300; thiamin 37; riboflavin 48; pyridoxine 20 ; cyanocobalamin 0.1 ; folic acid 10 ; calcium pantothenate 74 ; menadione 11 ; ascorbic acid 240 ; myo-inositol 337 ; biotin 0.5 ; nicotinic acid 300 [23].

Mineral mixture contained (as g kg-1 dry diet): $\mathrm{Ca}\left(\mathrm{H}_{2} \mathrm{PO}_{4}\right)_{2} \mathrm{H}_{2} \mathrm{O}, 6.80 ; \mathrm{Ca}\left(\mathrm{C}_{6} \mathrm{H}_{10} \mathrm{O}_{6}\right) \cdot 3 \mathrm{H}_{2} \mathrm{O}, 17.42767 ; \mathrm{FeSO} \cdot 7 \mathrm{H}_{2} \mathrm{O}, 0.25 ; \mathrm{MgSO}_{4} 7 \mathrm{H}_{2} \mathrm{O}, 6.60$ $\mathrm{K}_{2} \mathrm{HPO}_{4}, 12.00 ; \mathrm{NaH}_{2} \mathrm{PO}_{4} \cdot \mathrm{H}_{2} \mathrm{O}, 4.40 ; \mathrm{NaCl}, 2.25 ; \mathrm{AlCl}_{3}, 0.0042 ; \mathrm{KI}, 0.0075 ; \mathrm{CuSO}_{4} \cdot 5 \mathrm{H}_{2} \mathrm{O}, 0.025 ; \mathrm{MnSO}_{4} \cdot \mathrm{H}_{2} \mathrm{O}, 0.035 ; \mathrm{CoCl}_{2} \cdot \mathrm{H}_{2} \mathrm{O}, 0.05 ; \mathrm{ZnSO}_{4} \cdot 7 \mathrm{H}_{2} \mathrm{O}$, $0.15 ; \mathrm{Na}_{2} \mathrm{SeO}_{3} \cdot 1.5 \mathrm{H}_{2} \mathrm{O}, 0.000635$.

${ }^{1}$ Yongsheng Feed Corporation, Binzhou, China; proximate composition (\% dry matter): moisture, 7.9; crude protein, 70.9; crude lipid, 10.1 .

${ }^{2}$ Yongsheng Feed Corporation, Binzhou, China; proximate composition (\% dry matter): moisture, 9.1; crude protein, 50.0; crude lipid, 1.32.

${ }^{3}$ Yongsheng Feed Corporation, Binzhou, China; proximate composition (\% dry matter): moisture, 10.0; crude protein, 55.4; crude lipid, 5.76.

${ }^{4}$ Yuxin Feed Corporation, Rongcheng, China; proximate composition (\% dry matter): moisture, 41.3; crude protein, 37.1; crude lipid, 6.2.

${ }^{5}$ Krillsea Operation AS, Fosnavåg, Norway; proximate composition (\% dry matter): moisture, 41.3; crude protein, 30.5; crude lipid, 8.2.

\section{Fish and feeding trial}

Mangrove red snapper Lutjanus argentimaculatus juveniles obtained from a commercial producer (Xincun Fish Farm, Linshui, Shanya, China) were reared by feeding a commercial diet in indoor culture systems where they were acclimated to experimental conditions at a density of 30 fish per tank for 2 weeks. After acclimation, fish (initial body weight: $1.46 \pm 0.02$ g mean \pm S.D.) were pooled and randomly distributed into $2 \mathrm{~L}$ fiberglass tanks in groups of 18 fish per tank. The feeding trial was conducted in 150-L fiberglass tanks connected as a closed recirculating system with coral-sand filter (25-cm thickness) and primary biological filter. Low-pressure electrical blowers provided aeration via air stones. Filtered water was supplied at a flow rate of $2.21 \mathrm{~min}-1$ to each tank, and water temperature was measured daily and maintained at $27 \pm 10 \mathrm{C}$. Dissolved oxygen (> $\left.7.05 \mathrm{mg} \mathrm{L}^{-1}\right)$, pH (8.05 - 8.23), salinity (30.1 - 33.2 $\left.\mathrm{g} \mathrm{L}^{-1}\right)$, and total ammonia $\left(<0.10 \mathrm{mg} \mathrm{N} \mathrm{L}^{-1}\right)$ were measured weekly using methods described in the work of Allan et al. [26]. Experiment fish were subjected to a 12 light: 12 dark photoperiod using fluorescent lighting during the experimental period.

Six experimental diets and one control diet were randomly assigned within the 21-tank system such that each dietary treatment was given to three tanks. Fish were hand-fed their prescribed diets to satiation, twice daily at $0800 \mathrm{~h}$ and $1700 \mathrm{~h}$ until pellets were first seen to sink to the bottom of the tank. Feed intake was recorded daily. Fish feces were cleaned by siphoning twice a day after feeding. The experiment continued for 8 weeks.

\section{Sampling}

At the end of the trial, fish were deprived of food for $16 \mathrm{~h}$ prior to sampling, and then the same protocol of slaughter by crushing the spinal cord of fish head with a needle was followed for each tank after the fish were euthanized (MS-222 at 10 $\mathrm{mg} \mathrm{L}^{-1}$ ). Four fish from each tank were randomly collected for analysis of whole-body composition. Eight fish per tank were blooded via heart puncture using heparinized syringes, and then individually weighed and dissected to separate and weigh the viscera, liver, intestine and intraperitoneal fat. White muscle was dissected from both sides of the fillets without skin. Plasma was separated by centrifugation at $3500 \times \mathrm{g}$ for $10 \mathrm{~min}$ and stored at $-700 \mathrm{C}$ until analysis of total protein (TP), cholesterol (CHOL), total tricylglycerol (TG), high density lipoprotein-cholesterol (HDL-C) and low density lipoprotein-cholesterol (LDL-C).

\section{Analytic methods}

Crude protein $(\mathrm{N} \times 6.25)$ was determined by the Kjeldahl method after acid digestion using an auto Kjeldahl System (1030-Auto-analyzer, Tecator, Sweden). Crude lipid was determined by ether extraction using a Soxtec System HT (Soxtec System HT6, Tecator, Sweden). Dry matter was analyzed by oven-drying at $105 \mathrm{C}$ for $24 \mathrm{~h}$ until constant weight. Crude ash was determined by incinerating samples at 550C in a muffle furnace for $24 \mathrm{~h}$. Plasma TP, CHOL, TG, HDL-C and LDL-C were determined using an automatic blood analyzer (Hitachi 7170A, Hitachi, Tokyo, Japan).

\section{Calculations}

The following formulas were used to compute various body condition indices: Condition factor (CF): 100× (live weight, g) / (body length, $\mathrm{cm})^{3}$; Hepatosomatic index (HSI): liver weight $\times 100$ / body weight; and Intraperitoneal Fat (IPF) Ratio: IPF weight $\times 100$ / body weight.

Fish performance was measured as: Weight gain (WG): 100 $\times$ (final mean weight-initial mean weight) / initial mean weight; Feed efficiency (FE): (final mean body weight-initial mean body weight) / Feed intake. Protein efficiency ratio (PER): g gain /g protein fed. Protein productive value (PPV):100 x retained protein (g) / protein fed (g).

\section{Statistic analysis}

All data are presented as means \pm S.D. and subjected to one-way analysis of variance (ANOVA) $(n=3)$ to test the effects of experimental diets using the software of SPSS (version 13.0) for Windows. Duncan's multiple range test was used to resolve differences among treatment means [27]. Differences among means were considered significant at $\mathrm{p}<0.05$. 


\section{Results}

\section{Growth performance and feed utilization}

Growth performance and feed utilization of fish were influenced by different dietary treatments (Table 2). Fish fed the (FM40+SM) diet and the (FM40+SM+FS) diet had relatively higher WG values than fish fed the (FM100) diet and the (FM40+SM+KS) diet, but the differences were not significant.
For fish fed the (FM40+PM) diet, WG was significantly lower $(p<0.05)$ compared to those values of fish fed the other diets. There were no significant differences in FI values among all experiment treatments. Fish did not show obvious variations in feed utilization, except that significantly lower FE, PER and PPV values were observed in fish fed on (FM40+PM) diet. Survival for fish fed different experiment diets was not significantly different $(\mathrm{p}>0.05)$.

Table 2: The growth performance and feed utilization of juvenile Lutianus argentimaculatus fed the experimental diets for 8 weeks ${ }^{1}$.

\begin{tabular}{|c|c|c|c|c|c|c|c|}
\hline \multirow{2}{*}{} & \multicolumn{7}{|c|}{ Diet Designation } \\
\cline { 2 - 8 } & (FM100) & $(F M 40+S M)$ & $(F M 40+S M+F S)$ & $(F M 40+S M+K M)$ & $(F M 40+P M)$ & $(F M 40+P M+F S)$ & $(F M 40+P M+K M)$ \\
\hline WG2 & $651 \pm 143 \mathrm{ab}$ & $741 \pm 130 \mathrm{a}$ & $764 \pm 75 \mathrm{a}$ & $656 \pm 90 \mathrm{ab}$ & $374 \pm 22 \mathrm{c}$ & $518 \pm 79 \mathrm{bc}$ & $685 \pm 74 \mathrm{ab}$ \\
\hline FI3 & $17.88 \pm 1.09$ & $18.90 \pm 2.10$ & $20.07 \pm 2.36$ & $16.84 \pm 1.51$ & $15.75 \pm 3.34$ & $16.00 \pm 3.26$ & $17.09 \pm 3.23$ \\
\hline FE4 & $0.51 \pm 0.10 \mathrm{a}$ & $0.60 \pm 0.07 \mathrm{a}$ & $0.58 \pm 0.07 \mathrm{a}$ & $0.59 \pm 0.02 \mathrm{a}$ & $0.35 \pm 0.06 \mathrm{~b}$ & $0.48 \pm 0.12 \mathrm{a}$ & $0.57 \pm 0.11 \mathrm{a}$ \\
\hline PER5 & $1.31 \pm 0.26 \mathrm{a}$ & $1.51 \pm 0.17 \mathrm{a}$ & $1.43 \pm 0.17 \mathrm{a}$ & $1.44 \pm 0.06 \mathrm{a}$ & $0.86 \pm 0.15 \mathrm{~b}$ & $1.18 \pm 0.29 \mathrm{ab}$ & $1.42 \pm 0.27 \mathrm{a}$ \\
\hline PPV6 & $0.24 \pm 0.05 \mathrm{a}$ & $0.29 \pm 0.04 \mathrm{a}$ & $0.29 \pm 0.04 \mathrm{a}$ & $0.28 \pm 0.02 \mathrm{a}$ & $0.15 \pm 0.02 \mathrm{~b}$ & $0.22 \pm 0.05 \mathrm{a}$ & $0.28 \pm 0.05 \mathrm{a}$ \\
\hline $\begin{array}{c}\text { Survival } \\
\text { (\%) }\end{array}$ & $96.3 \pm 3.2$ & $94.4 \pm 5.6$ & $90.7 \pm 8.5$ & $98.1 \pm 3.2$ & $85.2 \pm 8.5$ & $87.0 \pm 17.9$ & $87.0 \pm 17.9$ \\
\hline
\end{tabular}

${ }^{1}$ Values are means \pm S.D. of three replicates and values within the same row with different letters are significantly different $(P<0.05)$. ${ }^{2}$ WG $(\%)=100 \times$ (final mean weight-initial mean weight) $/$ initial mean weight.

${ }^{3} \mathrm{FI}\left(\mathrm{g}\right.$ fish $\left.{ }^{-1}\right)$ : Feed intake (as dry matter basis).

${ }^{4} \mathrm{FE}=(\mathrm{FBW}-\mathrm{IBW}) /$ Feed intake.

${ }^{5} \mathrm{PER}=\mathrm{g}$ gain $/ \mathrm{g}$ protein fed.

${ }^{6} \mathrm{PPV}=$ retained protein $(\mathrm{g}) /$ protein fed $(\mathrm{g})$.

Morphological indices, whole-body compositions, and plasma indices

Condition factor (CF) (Table 3) kept relatively constant among all dietary treatments. Hepatosomatic index (HSI) for fish fed the $(\mathrm{FM} 40+\mathrm{PM})$ diet was significantly lower $(\mathrm{p}<0.05)$ than that of fish fed the other soybean meal or peanut meal containing diets. Intraperitoneal fat (IPF) ratio of fish fed on the $(\mathrm{FM} 40+\mathrm{SM}+\mathrm{FS})$ diet or $(\mathrm{FM} 40+\mathrm{PM}+\mathrm{FS})$ diet were significantly higher compared to other experiment groups, with the exception of the (FM40+PM+KS) group. There was a significantly higher $(\mathrm{p}<0.05)$ value of moisture content, but lower value of whole-

Table 3: Body condition indices of juvenile Lutianus argentimaculatus fed the experimental diets for 8 weeks

\begin{tabular}{|c|c|c|c|c|c|c|c|}
\hline & \multicolumn{7}{|c|}{ Diet Designation } \\
\hline & (FM100) & (FM40+SM) & $(\mathrm{FM} 40+\mathrm{SM}+\mathrm{FS})$ & $(\mathrm{FM} 40+\mathrm{SM}+\mathrm{KM})$ & $(\mathrm{FM} 40+\mathrm{PM})$ & $(\mathrm{FM} 40+\mathrm{PM}+\mathrm{FS})$ & $(\mathrm{FM} 40+\mathrm{PM}+\mathrm{KM})$ \\
\hline $\mathrm{CF}^{2}$ & $1.88 \pm 0.07^{\mathrm{ab}}$ & $1.96 \pm 0.01^{\mathrm{a}}$ & $1.88 \pm 0.12^{\mathrm{ab}}$ & $1.78 \pm 0.03^{\mathrm{b}}$ & $1.76 \pm 0.03^{\mathrm{b}}$ & $1.89 \pm 0.10^{\mathrm{ab}}$ & $1.86 \pm 0.08^{\mathrm{ab}}$ \\
\hline $\mathrm{HSI}^{3}$ & $2.78 \pm 0.40^{\mathrm{a}}$ & $2.95 \pm 0.21^{\mathrm{a}}$ & $3.12 \pm 0.11^{\mathrm{a}}$ & $2.98 \pm 0.17^{\mathrm{a}}$ & $1.73 \pm 0.33^{\mathrm{b}}$ & $2.95 \pm 0.39^{\mathrm{a}}$ & $2.14 \pm 0.25^{\mathrm{b}}$ \\
\hline IPF ratio ${ }^{4}$ & $1.02 \pm 0.05^{\mathrm{b}}$ & $1.61 \pm 0.15^{b}$ & $2.44 \pm 0.26^{\mathrm{a}}$ & $1.26 \pm 0.28^{b}$ & $1.13 \pm 0.31^{b}$ & $2.30 \pm 0.72^{\mathrm{a}}$ & $2.54 \pm 0.40^{\mathrm{a}}$ \\
\hline
\end{tabular}

body lipid content in the (FM40+PM) group when compared to other experiment groups. Fish fed on the (FM40+PM) diet displayed significantly lower $(\mathrm{p}<0.05)$ whole-body protein content (Table 4) than fish fed on the $(\mathrm{FM} 40+\mathrm{SM})$ diet, the $(\mathrm{FM} 40+\mathrm{SM}+\mathrm{FS})$ diet, the $(\mathrm{FM} 40+\mathrm{SM}+\mathrm{KS})$, the $(\mathrm{FM} 40+\mathrm{PM}+\mathrm{FS})$ diet, or the $(\mathrm{FM} 40+\mathrm{PM}+\mathrm{KS})$ diet. Plasma total protein (TP), cholesterol (CHOL), total tricylglycerol (TG) and high density lipoprotein-cholesterol (HDL-C) for experiment fish were only slightly influenced by the different dietary treatments (Table 5). The value of low density lipoprotein-cholesterol (LDL-C) in the $(\mathrm{FM} 40+\mathrm{PM}+\mathrm{FS})$ group was significantly higher $(\mathrm{p}<0.05)$ than that of LDL-C in the FM100 or (FM40+SM+KS) group. 


\section{Oceanography \& Fisheries Open Access Journal}

${ }^{1}$ Values are means \pm S.D. of three replicates and values within the same row with different letters are significantly different $(P<0.05)$.

${ }^{2} \mathrm{CF}$ (condition factor) $=100 \times$ (live weight, $\left.\mathrm{g}\right) /$ (body length, $\left.\mathrm{cm}\right)^{3}$.

${ }^{3}$ Hepatosomatic index $(\mathrm{HSI})=$ liver weight $\times 100 /$ body weight.

${ }^{4}$ Intraperitoneal fat (IPF) ratio $=$ IPF weight $\times 100 /$ body weight.

Table 4: The whole-body compositions (fresh-weight basis) of juvenile Lutianus argentimaculatus fed the experimental diets for 8 weeks ${ }^{1}$

\begin{tabular}{|c|c|c|c|c|c|c|c|}
\hline \multirow{2}{*}{} & \multicolumn{7}{|c|}{ Diet Designation } \\
\cline { 2 - 8 } & $(\mathrm{FM} 100)$ & $(\mathrm{FM} 40+\mathrm{SM})$ & $(\mathrm{FM} 40+\mathrm{SM}+\mathrm{FS})$ & $(\mathrm{FM} 40+\mathrm{SM}+\mathrm{KM})$ & $(\mathrm{FM} 40+\mathrm{PM})$ & (FM40+PM+FS) & $(\mathrm{FM} 40+\mathrm{PM}+\mathrm{KM})$ \\
\hline Whole body & & & & & & & \\
\hline Moisture (\%) & $71.77 \pm 1.49 \mathrm{~b}$ & $70.52 \pm 0.21 \mathrm{~b}$ & $70.22 \pm 1.67 \mathrm{~b}$ & $71.57 \pm 0.32 \mathrm{~b}$ & $73.99 \pm 0.82 \mathrm{a}$ & $71.50 \pm 0.24 \mathrm{~b}$ & $70.71 \pm 0.78 \mathrm{~b}$ \\
\hline Protein (\%) & $18.35 \pm 0.59 \mathrm{~cd}$ & $19.46 \pm 0.59 \mathrm{ab}$ & $20.11 \pm 0.54 \mathrm{a}$ & $19.24 \pm 0.34 \mathrm{abc}$ & $17.56 \pm 1.00 \mathrm{~d}$ & $18.98 \pm 0.31 \mathrm{bc}$ & $19.49 \pm 0.47 \mathrm{ab}$ \\
\hline Lipid (\%) & $5.88 \pm 0.59 \mathrm{~b}$ & $8.49 \pm 0.16 \mathrm{a}$ & $6.54 \pm 0.70 \mathrm{~b}$ & $6.29 \pm 0.26 \mathrm{~b}$ & $4.25 \pm 0.69 \mathrm{c}$ & $5.80 \pm 0.60 \mathrm{~b}$ & $6.77 \pm 0.4$ \\
\hline
\end{tabular}

${ }^{1}$ Values are means \pm S.D. of three replicates and values within the same row with different letters are significantly different $(P<0.05)$.

Table 5: The plasma composition of juvenile Lutianus argentimaculatus fed the experimental diets for 8 weeks [1].

\begin{tabular}{|c|c|c|c|c|c|c|c|}
\hline \multirow{2}{*}{} & \multicolumn{7}{|c|}{ Diet Designation } \\
\cline { 2 - 8 } & $(\mathrm{FM} 100)$ & $(\mathrm{FM} 40+\mathrm{SM})$ & $(\mathrm{FM} 40+\mathrm{SM}+\mathrm{FS})$ & $(\mathrm{FM} 40+\mathrm{SM}+\mathrm{KM})$ & $(\mathrm{FM} 40+\mathrm{PM})$ & $(\mathrm{FM} 40+\mathrm{PM}+\mathrm{FS})$ & $(\mathrm{FM} 40+\mathrm{PM}+\mathrm{KM})$ \\
\hline TP (g L-1)a & $41.73 \pm 8.6$ & $43.20 \pm 6.17$ & $41.47 \pm 3.62$ & $43.20 \pm 7.25$ & $40.73 \pm 6.80$ & $37.07 \pm 1.55$ & $43.60 \pm 9.25$ \\
\hline $\begin{array}{c}\text { TG (mmol } \\
\text { L-1)b }\end{array}$ & $4.57 \pm 0.50$ & $3.43 \pm 1.71$ & $3.03 \pm 0.35$ & $3.87 \pm 1.62$ & $4.50 \pm 1.56$ & $3.07 \pm 0.55$ & $3.83 \pm 0.76$ \\
\hline $\begin{array}{c}\text { CHOL (mmol } \\
\text { L-1)c }\end{array}$ & $4.47 \pm 0.93$ & $4.63 \pm 1.25$ & $4.00 \pm 0.17$ & $4.80 \pm 1.51$ & $4.90 \pm 0.53$ & $4.17 \pm 0.21$ & $5.10 \pm 0.43$ \\
\hline $\begin{array}{c}\text { HDL-C } \\
(\mathrm{mmol} \text { L-1)d }\end{array}$ & $2.13 \pm 0.42$ & $2.40 \pm 0.75$ & $2.13 \pm 0.06$ & $2.13 \pm 0.64$ & $2.07 \pm 0.06$ & $2.03 \pm 0.15$ & $2.37 \pm 0.23$ \\
\hline $\begin{array}{c}\text { LDL-C } \\
(\mathrm{mmol} \mathrm{L-1)e}\end{array}$ & $0.46 \pm 0.27 \mathrm{c}$ & $0.67 \pm 0.29 \mathrm{abc}$ & $0.49 \pm 0.13 \mathrm{bc}$ & $0.91 \pm 0.26 \mathrm{ab}$ & $0.79 \pm 0.19 \mathrm{abc}$ & $0.74 \pm 0.23 \mathrm{abc}$ & $0.99 \pm 0.10 \mathrm{a}$ \\
\hline
\end{tabular}

${ }^{1}$ Values are means \pm S.D. of three replicates and values within the same row with different letters are significantly different $(P<0.05)$.

aTP: total protein; ${ }^{\mathrm{T} T G}$ : total tricylglycerol; ${ }^{\mathrm{C}} \mathrm{CHOL}$ : cholesterol.

dHDL-C: high density lipoprotein-cholesterol; 'LDL-C: low density lipoprotein-cholesterol.

\section{Discussion}

This study indicated that $60 \%$ of dietary FM protein could be replaced by soybean meal, or by a mixture of peanut meal and $10 \%$ KS without affecting Lutjanus argentimaculatus growth performance. Results of $680 \%-760 \%$ WG for fish fed with a diet consisting of $40 \%$ crude protein, $9 \%$ lipid and a $60 \%$ replacement of fishmeal by soybean meal or peanut meal in this study were comparable to previous results reported for this fish species [21] or reported for other fish species $[5,7,28]$. A previous study of Catacutan and Pagador [22] had shown that 25\% fishmeal protein, and even higher levels with a bio-available phosphorus supplementation, could be replaced by soybean-meal protein, without inducing the growth of Lutjanus argentimaculatus, when fed with diets containing $50 \%$ crude protein and $10 \%$ crude lipid.

Growth performance differences observed between the (FM40+PM) group and the (FM40+PM+KS) group demonstrated that $10 \%$ KS supplementation had a positive influence on the growth of Lutjanus argentimaculatus fed on a peanut-mealcontaining diet. A previous study pointed out that KM has been successfully used in the diets for Atlantic salmon as the main protein source but slightly reduced fish growth was observed when totally replacing FM [29]. Interestingly, it was observed that fish growth in the (FM40+SM+KS) group was not improved when compared to those in the (FM40+SM) group. In this study, for both the soybean-meal-containing group and the peanut-mealcontaining group, $10 \%$ FS supplementation did not significantly affect fish growth. These results were not in accordance with the reports of Kousoulaki et al. [15], in which FS was reported to have a stimulation effect on Atlantic salmon's growth after fish were fed on a diet high in plant proteins.

Limited palatability of the high plant protein diets has been recognized as one of the main negative effects for marine fish. In this study, no significant variation in feed intake values were observed among all experiment treatments, confirming that $60 \%$ replacement of FM protein by soybean meal or peanut meal as well as a $10 \%$ FS or KS supplementation had no remarkable effects on diet palatability for Lutjanus argentimaculatus. These results did not comply with the reports with red sea 
bream [16] and largemouth bass [30], which may be explained by differences in fish species or in nutrient levels of the crude ingredients supplemented in experiment diets. In those studies above, FS contained $73.4 \%$ crude protein and $4.0 \%$ crude lipid, and KM contained $62.1 \%-64.5 \%$ crude protein and $23.4 \%$ crude lipid. In the present study, crude protein levels in FS and KS were $37.1 \%$ and $30.5 \%$, respectively, and for crude lipid levels, values were $6.2 \%(\mathrm{FS})$ and $8.2 \%(\mathrm{KS})$, respectively.

An obvious relationship was observed between fish growth performance (WG) and fish feed utilization (FE, PER, PPV). The lower feed utilization of fish fed the (FM40+PM) diet may be due to its reduced digestibility, nutrient imbalances or anti-nutritional factors, and this needs to be further studied. Comparisons of results of growth performance and feed utilization between fish fed the $(\mathrm{FM} 40+\mathrm{PM}+\mathrm{FS})$ diet, the $(\mathrm{FM} 40+\mathrm{PM}+\mathrm{KS})$ diet and the (FM40+PM) diet, confirmed that $10 \%$ dietary FS or $10 \%$ dietary KS supplementation could compensate some nutrient deficiency or insufficiency in diets containing high peanut meal for Lutjanus argentimaculatus. Additionally, in all diets containing FS and KS in this study, fish growth performance was not negatively affected. These results indicated that FS and KS may contain some free essential amino acids or small peptides, which agree with reports of previous studies $[15,16,23,26]$.Values of hepatosomatic index in the $(\mathrm{FM} 40+\mathrm{PM})$ and $(\mathrm{FM} 40+\mathrm{PM}+\mathrm{KM})$ treatments were significantly lower than that of value in the fishmeal based control treatment or other experimental treatments, which indicated that liver histology may be affected by the inclusion of PM. In Japanese Seabass, a $60 \%$ or $80 \%$ replacement of FM by an animal protein blend induced hepatic steatosis [31], but in Sharpsnout sea bream [32] and Gilthead Sea Bream [33], fish liver histology was not affected by sunflower meal or carob seed germ meal substituted for FM. Though effects of the replacement of FM on fish liver morphology depends on different substituted materials and different fish species, further studies should be undertaken to establish effects of high inclusion levels of plant protein on Lutjanus argentimaculatus health.

Higher values of IPF ratios and whole-body lipid contents observed in the (FM40+SM) group indicated that the replacement of fishmeal by soybean meal would induce lipid deposition in fish, which accorded with the results of Catacutan and Pagador [22]. These results may be attributed to insufficiency of phosphorus in high-plant stuff contained diets [34]. A lower value of wholebody lipid content existed in the (FM40+PM) group compared to other groups may be due to the lower feed efficiency. In this study, it was observed that there were no significant differences in values of whole-body lipid contents between the (FM100) group and the (FM40+SM+FS), or (FM40+SM+KM), or $(\mathrm{FM} 40+\mathrm{PM}+\mathrm{FS})$, or $(\mathrm{FM} 40+\mathrm{PM}+\mathrm{KM})$ group, which indicated that the supplementation of FS or KM had an effect on lipid deposition of mangrove red snapper.

Plasma TP, CHOL, TG, HDL-C and LDL-C were also measured in this study, and these indices were not remarkably influenced by different dietary treatments. These results may indicate that fish had a relatively good physiological response to experiment diets and were under healthy conditions after being fed such diets. As reported by Kader et al. [5], blood parameters are important tools for the indication of physiological stress response as well as the general health condition of fish. Plasma TP content and TG content in this study were comparable to the values of Atlantic Salmon [28], but plasma CHOL content was lower than those values of Yellowfin Searbream [35] and Spotted Rose Snapper [9]. Plasma substrate concentrations are affected by many factors such as the transcript capability of epidermal cells of the intestine, the transcript capability of other transport-factors in target cells, and the metabolic ability of the fish digestive system to absorb nutrients.

In conclusion, $60 \%$ replacement of FM by soybean meal can be achieved in juvenile mangrove red snapper diets without any reduction in growth performance. On the other hand, the peanut meal substitution to FM at a $60 \%$ level, significantly reduced fish growth performance in the absence of $10 \%$ FS or KS supplementation.

\section{Acknowledgement}

This work was supported by Start-up fund Research of Hainan University (kyqd1041), Youth Foundation of Hainan University (qnjj1009), Foundation of Hainan Educational Commi (Hjkj2011-15). The authors would like to thank Huaihong Wang, Feiteng Guo, Nan Wang, Danlu Xu and Xianyun Wen for the sample processing. We are also very thankful to the anonymous reviewers and editor for their constructive and detailed comments on our manuscript.

\section{Reference}

1. FAO (2009) The state of the world fisheries and aquaculture FAO, Fisheries and Aquaculture Department, Rome, Italy.

2. Savolainen LC, Gatlin DM (2010) Evaluation of amino acid and zinc supplements to soybean-meal-based diets for hybrid striped bass. Aquaculture 307(3-4): 260-265.

3. Cabral EM, Fernandes TJR, Campos SD, Castro-Cunha M, Oliveira MBPP, et al. (2013) Replacement of fish meal by plant protein sources up to $75 \%$ induces good growth performance without affecting flesh quality in on-growing Senegalese sole. Aquaculture 380-383: 130138.

4. Brinker A, Reiter R (2011) Fish meal replacement by plant protein substitution and guar gum addition in trout feed, Part I: Effects on feed utilization and fish quality. Aquaculture 310(3-4): 350-360.

5. Kader MA, Bulbul M, Koshio S, Ishikawa M, Yokoyama S, et al. (2012) Effect of complete replacement of fishmeal by dehulled soybean meal with crude attractants supplementation in diets for red sea bream, Pagrus major. Aquaculture 350-353: 109-116.

6. Jorge Dias, Luís EC Conceição, Ana Ramalho Ribeiro, Pedro Borges, Luísa MP Valente, et. al. (2009) Practical diet with low fish-derived protein is able to sustain growth performance in gilthead seabream (Sparus aurata) during the grow-out phase. Aquaculture 293(3-4): 255-262.

7. Lim SJ, Lee KJ (2009) Partial replacement of fish meal by cottonseed meal and soybean meal with iron and phytase supplementation for 
parrot fish Oplegnathus fasciatus. J Aquaculture 290(3-4): 283-289.

8. Fuertes JB, Celada JD, Carral JM, Royuela MS, Rodriguez AG (2012) Effects of dietary protein and different levels of replacement of fish meal by soybean meal in practical diets for juvenile crayfish (Pacifastacus leniusculus, Astacidae) from the onset of exogenous feeding. Aqauculture 364-365: 338-344.

9. Carrillo YS, Hernández C, Hardy RW, Rodriguez BG, Vargasmachuca SC (2012) The effect of substituting fish meal with soybean meal on growth, feed efficiency, body composition and blood chemistry in juvenile spotted rose snapper Lutjanus guttatus (Steindachner, 1869). Aquaculture 364-365: 180-185.

10. Yue YR, Liu YJ, Tian LX, Gan L, Yang HJ, et al. (2012) Effects of replacing fish meal with soybean meal and peanut meal on growth, feed utilization and haemolymph indexes for juvenile white shrimp Litopenaeus vannamei, Boone. Aquaculture Research 43(11): 16871696.

11. Wu XY, Liu YJ, Tian LX, Mai KS, Yang HJ (2006) Apparent Digestibility Coefficients of Selected Feed Ingredients for Yellowfin Seabream, Sparus latus. Journal of the World Aquaculture Society 37(3): 237245.

12. Lugo MG, Olvera-Novoa MA (2008) Potential of the use of peanut (Arachis hypogaea) leaf meal as a partial replacement for fish meal in diets for Nile tilapia (Oreochromis niloticus L). Aquaculture Research 39(12): 1299-1306.

13. Rowland SJ, Allan GL, Mifsud C, Read PA, Glendenning D, et al. (2007) Effects of diets with different plant proteins on the performance of silver perch (Bidyanus bidyanus Mitchell) and on water quality in earthen ponds. Aquaculture Research 38(7): 748-756.

14. Cai C, Song L, Wang Y, Wu P, Ye Y, et al. (2013) Assessment of the feasibility of including high levels of rapeseed meal and peanut meal in diets of juvenile crucian carp (Carassiusauratusgibeliox Cyprinuscarpio): Growth, immunity, intestinal morphology, and microflora. Aquaculture 410-411: 203-215.

15. Kousoulaki K, Albrektsen S, Langmyhr E, Olsen HJ, Campbell P, et al. (2009) The water soluble fraction in fishmeal (stickwater) stimulates growth in Atlantic salmon (Salmo salar L) given high plant protein diets. Aquaculture 289(1-2): 74-83.

16. Kader MA, Koshio S, Ishikawa M, Yokoyama S, Bulbul M (2010) Supplemental effects of some crude ingredients in improving nutritive values of low fishmeal diets for red sea bream, Pagrus major. Aquaculture 308(3-4): 136-144.

17. Leu MY, Chen IH and Fang LS (2003) Natural spawning and rearing of mangrove red snapper, Lutjanus argentimaculatus, larvae in captivity. Bamidgeh 55(1): 22-30.

18. Liao IC, Su MS, Chang SL (1995) A Review of the Nursery and Growout Techniques of High-value Marine Finshes in Taiwan. In: Main, KL, Rosenfeld, C (Eds.), Culture of High-Value Marine Fishes. Oceanic Institute, Hawaii, pp. 121-137.

19. Emata AC, Borlongan IG (2003) A practical broodstock diet for the mangrove red snapper, Lutjanus argentimaculatus. Aquaculture 225(1-4): 83-88.

20. Catacutan MR, Pagador GE and Teshima S (2001) Effect of dietary protein and lipid levels and protein to energy ratios on growth, survival and body composition of the mangrove red snapper, Lutjanus argentimaculatus (Forsskal 1775). Aquaculture Research 32(10): 811-818.
21. Abbas G, Siddiqui PJA (2013) The effects of varying dietary protein level on growth, feed conversion, body composition and apparent digestibility coefficient of juvenile mangrove red snapper, Lutjanus argentimaculatus (Forsskal 1775). Aquaculture Research 44(5): 807818.

22. Catacutan MR, Pagador GE (2004) Partial replacement of fishmeal by defatted soybean meal in formulated diets for the mangrove red snapper, Lutjanus argentimaculatus (Forsskal 1775). Aquaculture Research 35(3): 299-306

23. Ibeas C, Rodríguez C, Badía P, Cejas JR, Santamaria FJ, et al. (2000) Efficacy of dietary methyl esters of n-3 HUFA vs. tricylglycerols of n-3 HUFA by gilthead seabream (Sparus aurata L) juveniles. Aquaculture 190(3-4): 273-287.

24. Kader MA (2008) Effects of Food Industry By-products on the Performances of Marine Fish, Dissertation for the Degree of Master of Science Kagoshima University, Japan, pp. 92.

25. Mai K, Li H, Ai Q, Duan Q Xu W, et al. (2006) Effects of dietary squid viscera meal on growth and cadmium accumulation in tissues of Japanese seabass, Lateolabrax japonicus (Cuvier1828). Aquaculture Research 37(11): 1063-1069.

26. Allan GF, Maguire GB, Hopkins SJ (1990) Acute and chronic toxicity of ammonia to juvenile Metapenaeus macleayi and Penaeus monodon and the influence of low dissolved-oxygen levels. Aquaculture 91(34): $265-280$.

27. Duncan DB (1955) Multiple-range and multiple F tests. Biometrics 11: 1-42.

28. Cabral EM, Bacelar M, Batista S, Cunha MC, Ozório ROA, et al. (2011) Replacement of fishmeal by increasing levels of plant protein blends in diets for Senegalese sole (Solea senegalensis) Juveniles. Aquaculture 322-323: 74-81.

29. Hansen JO, Penn M, Øverland M, Shearer KD, Krogdahl A, et al. (2010) High inclusion of partially deshelled and whole krill meals in diets for Atlantic salmon (Salmo salar). Aquaculture 310(1-2): 164-172.

30. Kubitza F, Lovshin LL (1997) The use of freeze-dried krill to feed train largemouth bass (Micropterus salmoides): feeds and training strategies. Aquaculture 148(4): 299-312.

31. Hu L, Yun B, Xue M, Wang J, Wu X, et al. (2013) Effects of fish meal quality and fish meal substitution by animal protein blend on growth performance, flesh quality and liver histology of Japanese seabass (Lateolabrax japonicus). Aquaculture 372-375: 52-61.

32. Mérida SN, Vidal AT, Llorens SM, Cerdá MJ (2010) Sunflower meal as a partial substitute in juvenile sharpsnout sea bream (Diplodus puntazzo) diets: Amino acid retention, gut and liver histology. Aquaculture 298(3-4): 275-281.

33. Llorens SM, Ariño RB, Mérida SN, Cerdá MJ, Vidal AT (2012) Carob seed germ meal as a partial substitute in gilthead sea bream (Sparus aurata) diets: Amino acid retention, digestibility, gut and liver histology. Aquaculture 338-341: 124-133.

34. Robaina L, Izquierdo MS, Moyano FJ, Socorro J, Vergara JM, et al. (1995) Soybean and lupin seed meals as protein sources in diets for gilthead sea bream (Sparus aurata): nutritional and histological implications. Aquaculture 130(2-3): 219-233.

35. Wu XY, Liu YJ, Tian LX, Mai KS, Yang HJ (2007) Utilization of different raw and pre-gelatinized starch sources by juvenile yellow fin seabream Sparus latus. Aquaculture Nutrition 13(5): 389-396. 